\title{
A long-term outlook on Russian oil industry facing internal and external challenges
}

\author{
Nikita O. Kapustin ${ }^{1, *}$ and Dmitry A. Grushevenko ${ }^{1,2}$ \\ ${ }^{1}$ The Department of Research of Energy Complex of Russia and the World, The Energy Research Institute of the Russian \\ Academy of Sciences, Nagornaya St., 31, k.2, 117186 Moscow, Russia \\ ${ }^{2}$ Center for Energy Markets Studies, The Energy Institute of the Higher School of Economics, Miasnickaya St., \\ 20, 101000 Moscow, Russia
}

Received: 22 April 2019 / Accepted: 16 July 2019

\begin{abstract}
Russian petroleum industry plays a vital part in both the country's economy and international hydrocarbon market, providing a third of state budget revenues and over $13 \%$ of global liquid hydrocarbon exports. Yet, nowadays the industry is facing a number of serious challenges, which threaten to undermine its sustainability. These challenges include depletion of the conventional oil resources, technological and economic sanctions and stagnating demand for liquid fuels, especially apparent in Russian traditional export destinations - Europe. The authors attempted to evaluate the impact of these issues and compile a forecast of Russian oil industry using state-of-the-art modelling tools. The calculations show, that even under fairly negative scenario assumptions, Russia is capable of maintaining crude oil and refined products exports above 250 mtoe up to 2040, remaining the world's second liquid hydrocarbon supplier. This, however, is still a huge drop from 425 mtoe of exports in 2018. To ensure sustainability the government and oil companies need to work in conjunction in several fields: facilitate geologic survey of conventional and promising oil and gas basins; domestic development of new oil extraction technologies for accessing unconventional and low-margin oil resources; provide transport infrastructure for remote fields; reforming tax system to better suit the new environment. This way, crude production can be maintained above 500 mtoe in the forecast period and exports even surpass 2018 levels. In any case, however, the need for massive investments and tax incentives coupled with global movement away from fossil fuels means, that in the future oil will be becoming less and less profitable for the state budget, thus Russian government needs to redouble efforts on economic diversification and energy transition.
\end{abstract}

\section{Introduction}

Russia is historically one of the major players in the global liquid hydrocarbons market, maintaining a position among the world's top three in crude oil and refined products output and exports for many years (Makarov et al., 2016). Yet, as of late, the country is facing a number of serious challenges, both internal and external in nature, threatening to undermine its status. The internal factors include:

- Scarcity of the resource base, readily available for commercial development (Bushuev et al. 2010; Henderson and Grushevenko, 2017; Minenergo of Russia, 2017; Mitrova and Grushevenko, 2017).

- Lack of domestic technology for accessing the offshore and unconventional oil resources and providing efficient refining (Kapustin and Grushevenko, 2016, 2018a; Kulagin et al., 2015).

\footnotetext{
* Corresponding author: nikita.kapustin@mail.ru
}

- Remoteness of prospective production areas from both domestic consumption centers and major export corridors (Henderson and Mitrova, 2016).

The external factors are the following:

- Mounting competition in the global oil market, becoming especially acute since the US shale oil boom (Dyl, 2018; Medlock et al., 2018).

- Declining demand in the traditional European market.

- Sanctions, imposed by the US and the EU, hurdling import of crucial technologies and capital (Mitrova et al., 2018; Nephew, 2019).

- Looming "Energy transition" capable of causing a global fossil fuels demand peak in the foreseeable future (IRENA, 2018; O'Connor, 2010).

The goal of this study is to access the gravity of the aforementioned challenges and to formulate a long-term 
outlook on the Russian oil sector's development, crude oil and refined products output and exports up to 2040 under the given conditions, using the state-of-the-art mathematical modelling tools, developed by ERI RAS.

\section{Methods}

For the purposes of this study the authors have implemented energy modelling complex SCANER, developed by ERI RAS research team (Makarov, 2011). The complex is comprised of multiple interconnected models, providing means for analyzing and forecasting all aspects of energy use related activities for both Russia and the world. For this particular research a number of modelling blocks were used most extensively:

- For the sake of forecasting liquid fuel demand a complex modelling tool combining "top-down" "bottomup" was utilized, described in Mitrova et al. (2015) and Grushevenko et al. (2018b);

- Crude oil production capacity for brownfield and greenfield projects was calculated using the Hubbert linearization approach covered by Mohr and Evans (2010) and Michaelides (2017);

- Russian oil refining forecasting is handled via simulation model, described by the authors in Kapustin and Grushevenko (2018a);

- The overall balance of Russian oil sector was composed through the application of World Oil Model (WOM). WOM is a static optimization model of full equilibrium. The model uses an extensive database, containing information on crude oil and NGL production capacities, oil refineries capacities, liquids transportation capacities and other characteristics of the petroleum industry as source data. The model covers the entire production chain of the oil market from extraction of crude to the production and marketing of petroleum products and alternative liquid fuels (Kapustin and Grushevenko, 2018b). Full description of the calculation algorithm is presented in the previous work by the authors (Kapustin and Grushevenko, 2017).

\section{Outlining the challenges and formulating scenario assumptions}

\subsection{Internal factors}

\subsubsection{Oil production}

In 2018 Russia came world's second in terms of oil production with 55584 mtoe, yet the country's current proven reserves of about 15 billion tons of oil equivalent (BP, 2018) place it only at 6th place. This disparity casts serious doubt on the long-term sustainability of production and export levels, which is one of the priority goals for the industry by Russian government, as evidenced by Russian energy strategy up 2035 project (Minenergo of Russia, 2017).

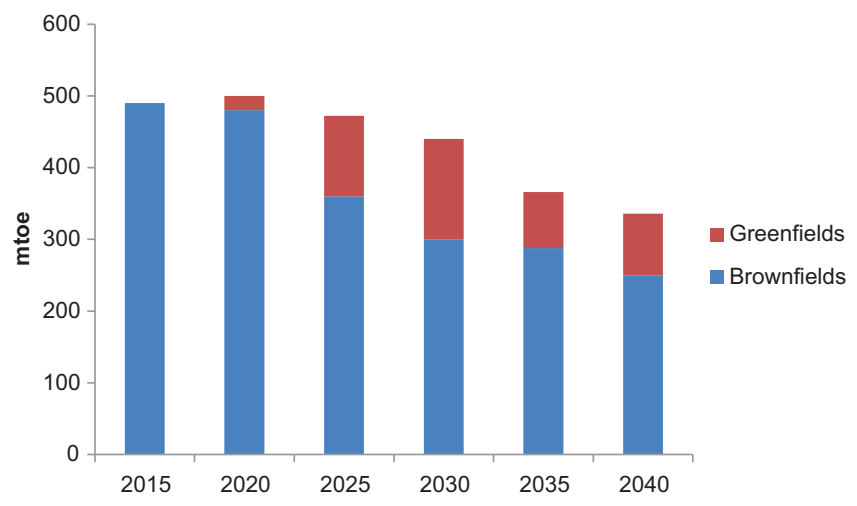

Fig. 1. Conventional oil production capacity outlook. Source: Authors' calculations.

Shrinking production capacities have been noted by both domestic (Makarov et al. 2016; Mitrova et al. 2018; Vygon and Kozlova, 2018) and international researcher (EIA, 2018; IEA, 2018). The author's analysis of over a hundred of Russian brownfields and most promising greenfield projects has shown a considerable reduction of production capability to just around 350 mtoe (excluding condensate) by 2040 (Fig. 1).

The underlying reasons are fairly obvious. Firstly, the decline of major fields in Volga-Ural and West Siberian basins, providing up to half of Russian oil output, is becoming increasingly hard to contain. Many fields produce an average of over $80 \%$ water at wellhead, legacy of dubious production intensification practices of the late Soviet era and the 90 's. At the same time, current greenfield projects lack in scale to truly replace the ailing giants, granting only a temporary boost in production (Henderson and Grushevenko, 2017), while prospective resources mostly consist of unconventional oil or are located in remote, hard-to-access areas, such as East Siberia and the Arctic shelf and are not readily available for development.

In addition to resource base constraints, other issues subsist. Firstly, much of the Russian pipeline infrastructure is geared towards transporting West Siberian oil towards the most populous European parts of the country and further, to the western borders, while the prospective resources of East Siberia and Russian Far East are still pretty much stranded. The ESPO pipeline (see Appendix I), which has been conceived as a mean to alleviate this problem has been operating at its full capacity of 58 million tons annually since 2016 (Onopriyk, 2017), limiting further developments in the region. The expansion of the transport corridor faces a typical "infrastructural paradox": government owned oil pipeline grid owner and operator Transneft is wary of making costly investment in further large-scale expansion under uncertain production growth prospects, while oil companies are wary of exploring and developing eastern basins with no viable means of actually delivering the crude to the consumers.

Secondly, average production costs of Russian crude are on the rise. During the oil price crisis of 2014-2016 Russian companies managed to drastically cut expenses. Rosneft, for instance, reported a staggering $72 \%$ reduction of 


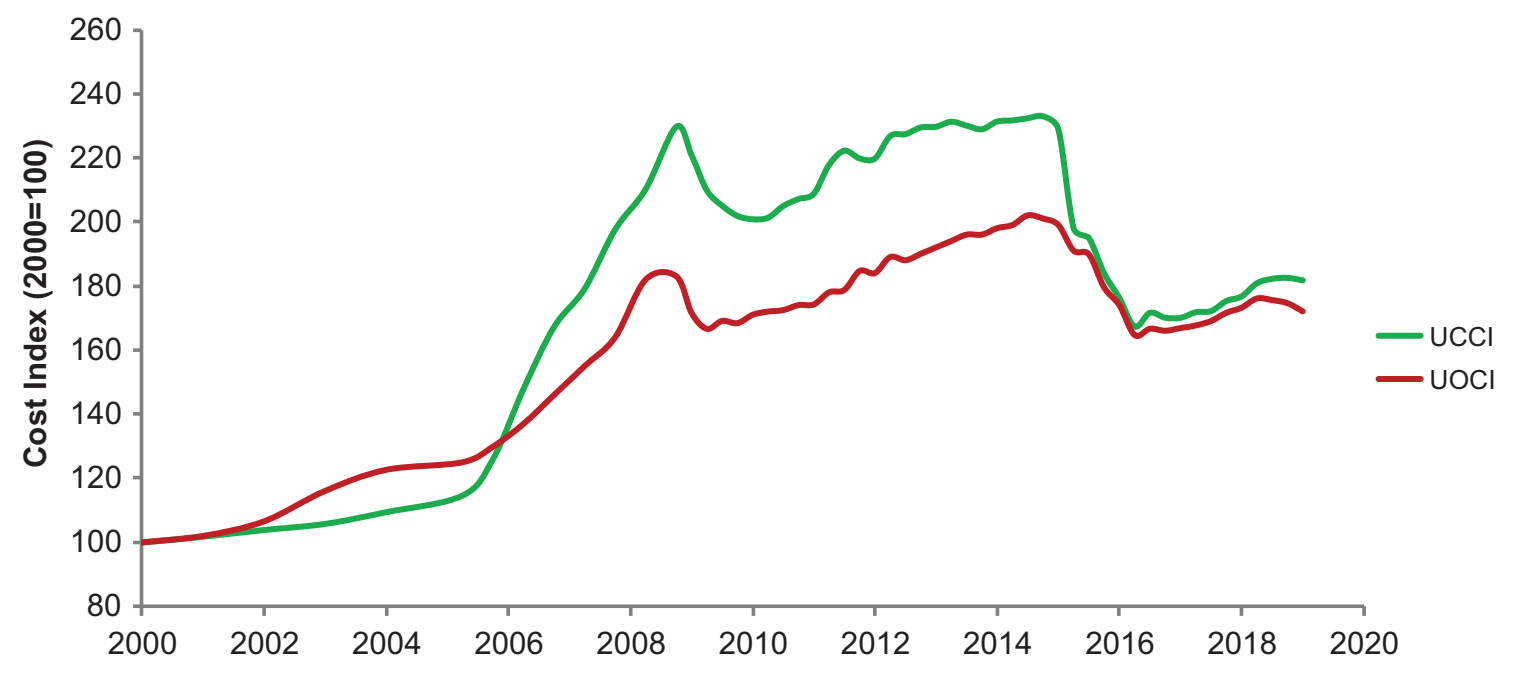

Fig. 2. Global Upstream Capital Cost Index (UCCI) and Upstream Operational Cost Index (UOCI). Source: IHS Markit.

operational expenses and 19\% reduction of net capital expenses in 2016 compared to 2013 (Rosneft, 2014, 2017). It was made possible by the devaluation of national currency and the reduction of tax burden due to the flexible Russian MET calculation system (EY, 2018; Grigoriev et al., 2018). However, by 2019 these options have exhausted themselves, and in 2018 the net OPEX and CAPEX have grown by 30 and $40 \%$ respectively. It is worth noting, that these dynamics were not exclusive to Russia. The fall of oil prices in 2014-2016 has forced most oil producers to cut capital and operational costs, which started to recover only recently (Fig. 2).

On average, the pre-tax uplifting costs of Russian oil are estimated at $25 \$$ /boe (Koroleva, 2019), which is still among the world's lowest, with only Saudi Arabia, Iran and Iraq producing cheaper (WSJ News Graphics, 2016). Add taxes and transport, however, and the figure doubles, placing Russian oil in the middle of the cost curve (Fig. 3). Moreover, most of the high-profile Greenfield projects, to some extent, benefit from tax cuts, thus each new barrel of oil generates less income for the federal budget still very much reliant on hydrocarbon revenues. Without the taxcuts, however, the low-margin projects come to a halt in a volatile price environment, as was the case with Tatarstan heavy oil in 2016, or are not launched at all.

On top of the resource base and economic issues, Russian oil industry suffers from technological deficiency, which was aggravated by sanctions by the US and EU. While undoubtly well-versed in conventional oil production, stemming from over a century of expertise, Russian oil industry has only recently faced the need to develop unconventional and offshore resources. After the turmoilous period of the 90 s, oil industry was one of the first to recover. This was in no small part due to extensive cooperation with foreign firms. In fact, by 2014 up to $80 \%$ of the needs of Russian oil industry were covered by imports (Molodtsov, 2018), thus, international cooperation appeared as a go-to solution to tap into the vast new reserves. This included the exploration and development of arctic shelf, culminating with the launch of Prirazlomnoye field project in 2013 (Gazprom, 2019), but even more importantly attempts at tackling the vast Bazhen formation, potentially containing billions upon billions tons of oil in tight bedrock, thus earning itself moniker "Russian Bakken" (Kapustin and Grushevenko, 2018b; Mitrova, 2013; RusEnergy, 2013). Known since the 70's but thought to be inaccessible; Bazhen re-emerged in expert discussions as the potential source of crude since the US tight oil boom. Russian producers sought to adopt the US expertise by establishing joint ventures with such companies as ExxonMobil, Shell and Dowell Schlumberger. With the introduction of sanctions in 2014 all of these projects were put on hold or cancelled (Tab. 1). However, the current volumes of production have not yet been affected, as the launch dates of those projects were scheduled beyond 2020. Currently, the start of production at Bazhen using strictly domestic technology is expected no earlier than 2025 and only if operating costs are reduced below $20 \$$ /boe (Kobzeva, 2018).

The situation is not without upsides, however. Realizing the challenges faced by the industry, Russian government is developing a tax reform. Since 2016 a number of projects have been greenlighted to voluntarily shift from the conventional production based mineral extraction tax (MET, known as "НДПИ" in Russia) to a more advanced Profit Based Tax (PBT), which is calculated based on the cash flow of the project. This move is expected to be beneficial for both producers and the government, as it effectively provides lowered taxation at the early phases of development, incentivizing investment into high-cost, low-margin fields, which would otherwise be left untouched, while ensuring higher taxes in the later stages, after the initial capital expenses have paid off (EY, 2018; Vygon et al., 2017).

The government sponsored import replacement programs, that have been initiated in 2015, at the heights of political crisis, have begun to bear fruit. The share of imports of heavy machinery has dropped to around $50 \%$, while domestic firms have increased turnover by almost 


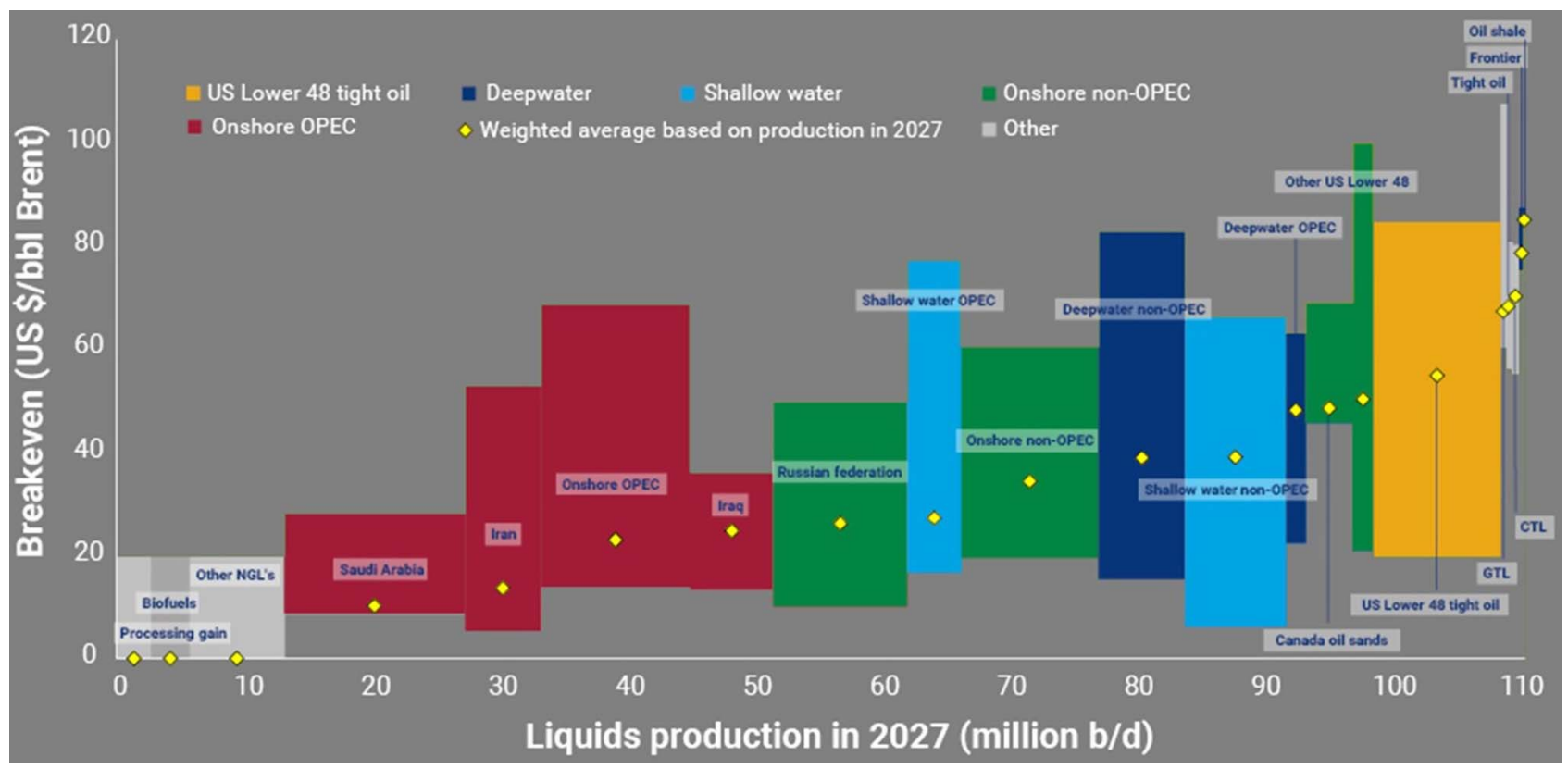

Fig. 3. Global cost curve. Source: Paton (2018).

$30 \%$, increasing both domestic sales and exports. Import substitution has stimulated pipe production, including large diameter pipes that have not been manufactured in Russia before. The software for geologic surveys and hydraulic fracturing is also being actively developed (Molodtsov, 2018).

The other positive is gas condensate. In 2018 its share in the overall liquid hydrocarbon production amounted to $7 \%$. As gas production in Russia is set to grow and more of it will be "wet" gas, so will condensate output increase in the foreseeable future, contributing to oil production.

For the sake of further calculations total production capacity of Russia has been split into five distinct groups:

1st - conventional brownfields and greenfields with production costs of $25 \$$ /boe;

2nd - gas condensate is a by-product of the gas industry, thus the production volumes are input exogenously at zero production cost;

3rd - conventional fields, situated in Russian Eastern Siberia and Far East, the development of which hinges on the expansion of ESPO;

4th - high-cost, low-margin fields, that require tax incentives, known in Russia as ТРИЗ (rus. Труднои звлекаемые Запасы - hard-do recover reserves);

5th - oil from Bazhen formation, recoverable only through the development of appropriate extraction technologies.

Our estimations show that full utilization of all the aforementioned production capacities can, in fact, ensure relatively stable production up to 2040 (Fig. 4). However, the actual realization of this potential will be determined by the demands of domestic and export markets, which will be discussed below.

\subsubsection{Oil refining and domestic demand}

Just under a half of crude oil, produced in Russia is exported (275 million out of 555 annually), while the rest is refined domestically. Russia is also one of the world's top refined products exporter, with over 120 mtoe supplied to the global market. At the same time, since 2014 refining volumes in Russia are in decline. After a period of lenient taxation, that has stimulated rapid development of the sector over almost a decade, the new policy is aimed at downsizing oil refining, cutting inefficient and excessive capacities, since, as demonstrated by ERI RAS research from 2014 and 2016, crude exports have easier time finding market niches and, at the same time, generate more profits for both oil companies and the government, especially since Russian products export mix is dominated by middle distillates (diesel) and residues (fuel oil, vacuum gas oil). The dynamics of Russian oil refining sector and its prospects has been discussed in more detail in the previous research by the authors (Kapustin and Grushevenko, 2018a). For the sake of this research it is worth noting, that the differentiated tax rates, that have put extra burden on the residue production have the potential of putting a whole quarter of Russian 300 million tons refining capacity out of business. Only the most technologically outfitted and efficient refineries are competitive in the current environment, constituting about 220-250 million tons of primary capacity.

There is, however, a natural limit for refining reduction which is dictated by the domestic demand. Ensuring a steady and abundant supply of motor fuels to the Russian market at relatively low prices is the cornerstone of the government's policy for oil refining in the interests of energy security and social stability (Kapustin and Grushevenko, 2018a). Thus, crude refining will always be at least at levels sufficient for covering the internal demand for gasoline and jet fuel. 
Table 1. Projects, stranded due to sanctions.

\begin{tabular}{|c|c|}
\hline Project & Participants \\
\hline
\end{tabular}

Joint shelf projects affected by the sanctions

Universitetskaya-1 well (Kara Sea) and Tuapsinskoye field in the (49\%) Black Sea
Joint venture between Rosneft (51\%) and Exxon

Projects: VostochnoPrinovozemelsky - 1, 2, 3; Severo-Karsky And UstOleneksky; Ust-Lensky; Anisina-Novosibirsky; Severo-Wrangelevsky - 1, 2, 3; Yuzhno-Chukotsky; The Tuapse Deflection Two objects in the Barents Joint venture between sea and Val-Shatskoye field Rosneft (67\%) and ENI in the Black sea $(33 \%)$

Joint venture between Rosneft (67\%) and Exxon $(33 \%)$
In 2011 Exxon and Rosneft had formed Postponed an alliance to explore and develop potentially vast but largely untapped reserves of Russian Arctic and Black Sea shelves. In September 2014 exploratory well drilled in the Kara Sea established the presence of significant oil and gas resources.

However, following the second round of sanctions adopted just a few days before the discovery; ExxonMobil suspended the project and withdrew from Russian joint ventures, writing off $\$ 1$ billion.

Exxon withdrew from the ventures in accordance with sanctions regulations.

In 2012, Rosneft and ENI signed an agreement on joint development of offshore fields in the Barents and Black seas.

Joint unconventional oil projects, affected by the sanctions

Bazhen and Achimov formations in the Western Siberia

Joint venture Trizneft Pilot SARL between Rosneft (51\%) and Exxon (49\%)

Development of Domanik Joint venture between deposits in Orenburg region Rosneft (51\%) and BP $(49 \%)$

Development of the Bazhen Joint venture between formation in KhantyMansiysk LUKOIL and Total
The companies planned joint evaluation of commercial development potential of unconventional oil of Bazhen and Achimov formations. ExxonMobil planned to invest 300 million dollars.

$B P$ planned to compensate part of Rosneft's past investment in Domanik deposits exploration and provide carry financing up to $\$ 300$ million. The pilot program was to be be implemented in two stages.

Companies planned joint exploration of three shale formations: VostochnoKovenskoye, Tashinskoye and Lyaminskoye in Khanty-Mansiysk. The investments were estimated at 120-150 million dollars.

Development of the Bazhen formation in KhantyMansiysk
Khanty-Mansiysk oil and JV received permits for the exploration gas Union JV between Shell of Uilsky-4, Uilsky-5 and Yuzhno$(50 \%)$ and Gazprom Neft $(50 \%)$
Rosneft announced independent development of the projects

Postponed

Postponed

Postponed

Total transferred its share in the project to $L U K O I L$

Shell suspended activities on the project 


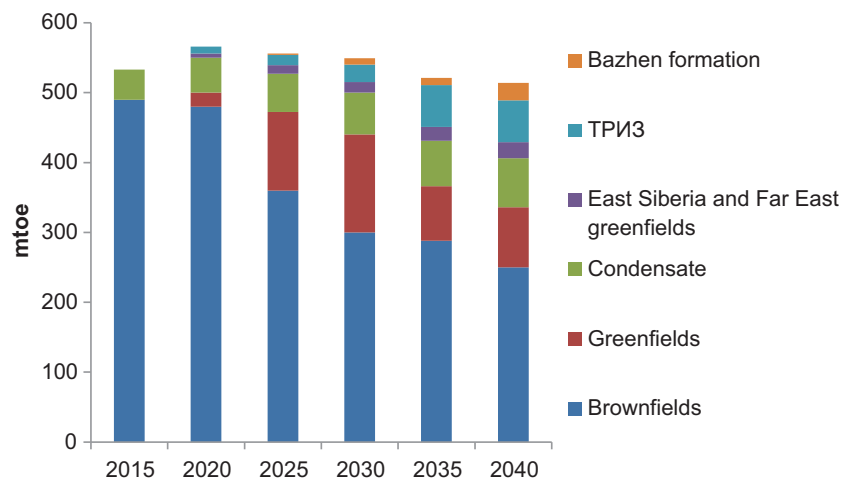

Fig. 4. The dynamics of production potential by source up to 2040. Source: Authors' calculations.

The domestic demand itself is slowing down, with struggling economy offering little grounds for substantial growth, while the government's efforts for fuel mix diversification put additional downwards pressure on conventional fuels as demonstrated in author's previous research (Grushevenko et al., 2018a). The future dynamics of the internal market will be instrumental for calculating the overall forecast of Russian oil sector. It and resource base assumptions will be covered in the following section.

\subsubsection{Internal scenario assumptions}

Summarizing the above, the following parameters have been identified as critical for developing a forecast of Russian oil sector: production capacity; refining capacity; domestic demand. Consequently, two scenarios have been formulated along these parameters, representing the general routes, which the development of Russian oil industry may adopt:

1. Baseline scenario, which is mostly a business-as-usual scenario. The rate of technological progress is sluggish, resulting in slower introduction of alternative fuels and energy efficient transport, and therefore higher overall domestic liquid fuel demand. At the same time, lack of technologies means that Bazhen formation and some of the costlier resources are not tapped into in the forecast period, limiting production potential.

2. Technological scenario assumes grassroots technological breakthrough in Russia, despite the sanctions and other limitations, allowing to fully utilize oil production potential, including LTO, simultaneously limiting oil products demand due to wider application of alternative fuels, mainly natural gas and LPG.

Domestic demand ranges from 155 to 141 mtoe across scenarios respectively, depending on the rate of displacement of conventional motor fuels, as mentioned before (Fig. 5). The relatively small difference between scenarios is due to the peculiarity of Russian domestic market, namely low elasticity of demand, which has been noted in

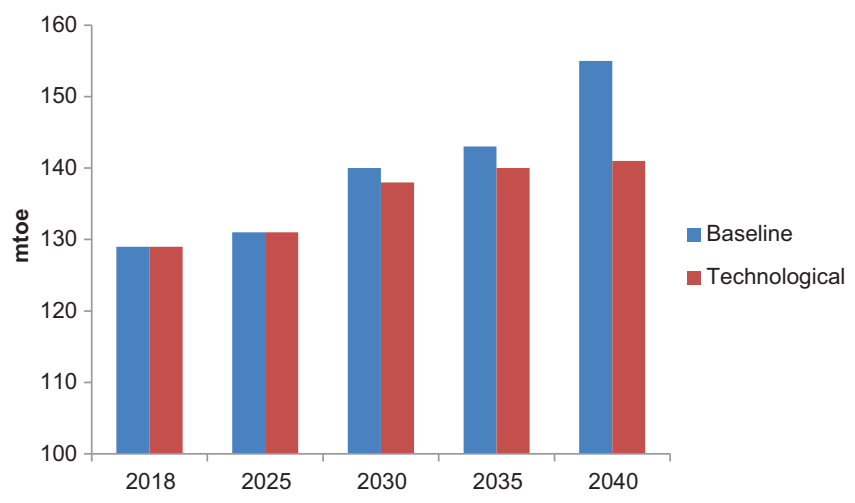

Fig. 5. Domestic liquid fuels demand scenarios in the forecast period. Source: Authors' research.

author's previous research (Grushevenko et al., 2018a, b). Thus, the impact of factors, such as pricing, GDP and government legislations is very limited.

\subsection{External factors}

As Russian oil industry is mostly export-oriented, making a meaningful forecast would be impossible without taking into account the shifting demand of international market and other external factors that can make or break the sector's development. For the sake of this study the authors required a balanced scenario of global energy development in the forecast period, built to avoid either the overestimation of potential oil demand (as with the Current Policies scenario of World Energy Outlook [IEA, 2017] or Baseline scenario of OPEC World Oil Outlook [OPEC 2016]), or excessive optimism about the transition to "New Energy" (like the scenarios of (DNV GL, 2018) or (McKinsey, 2019), which assume peak oil demand around 2020).

As such, the authors have used the "Probable" scenario of Global and Russian Energy Outlook 2016 (Makarov et al., 2016). This scenario assumes a fairly inertial route of the world's development, which leaves enough room for Russia to adapt to its specific issues, described above and maintain a significant role global energy, at the same time providing enough outside challenges to tests the sustainability of the country's related industries, in this case, oil sector and put reasonable limits on its expansion. In quantitative terms the scenario assumes that the global oil demand increases over the whole of the forecast period, albeit at decelerating pace, from 4391 mtoe in 2017 to 4751 mtoe in 2040, while oil prices remain at $65 \mathrm{US} \$ /$ boe until 2020 , then gradually increase to 90 US $\$$ /boe by 2040 . A more detailed description of scenario is presented in Table 2.

\section{Results and discussions}

The calculations show that Russia most probably would not be able to fully utilize its production potential. In the 
Table 2. Scenario assumptions.

\begin{tabular}{llll}
\hline Indicator & Period & Unit & Probab \\
\hline Demography and economy & & & \\
Global population & 2015 & Billion people & 7,40 \\
& 2020 & & 7,80 \\
& 2030 & & 8,50 \\
Global annual GDP growth & 2040 & & 9,20 \\
& 2015 & $\%$ & 2,80 \\
& 2030 & & 3,30 \\
Average global per capita & 2015 & US $\$ 1,0002014$ & 3,00 \\
GDP & 2040 & & 24,50 \\
& & & 24,70
\end{tabular}

Geopolitics, state energy policies, climate

Geopolitical risks

State energy policies

$\mathrm{CO}_{2}$ prices

Global ETS state

Technology

Technological development

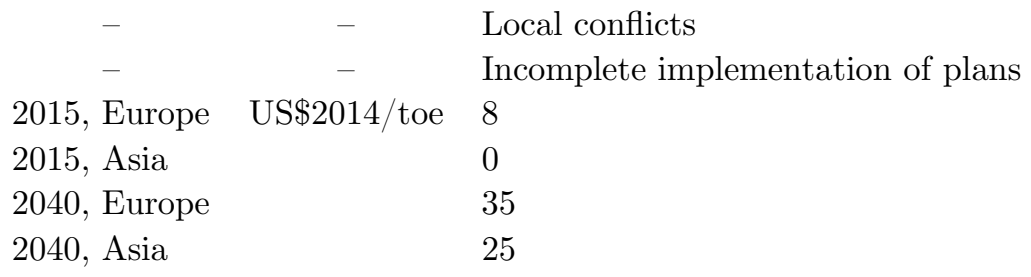

Undeveloped, but regional carbon markets emerge

Transfer of technologies

No technological breakthroughs are expected. It is assumed that only those technologies that are currently being tested will be introduced. Existing technologies will undergo a gradual increase in their cost effectiveness, along with a continuation of the existing trend of declining GDP energy intensity in each country.

Source: Makarov et al. (2016).

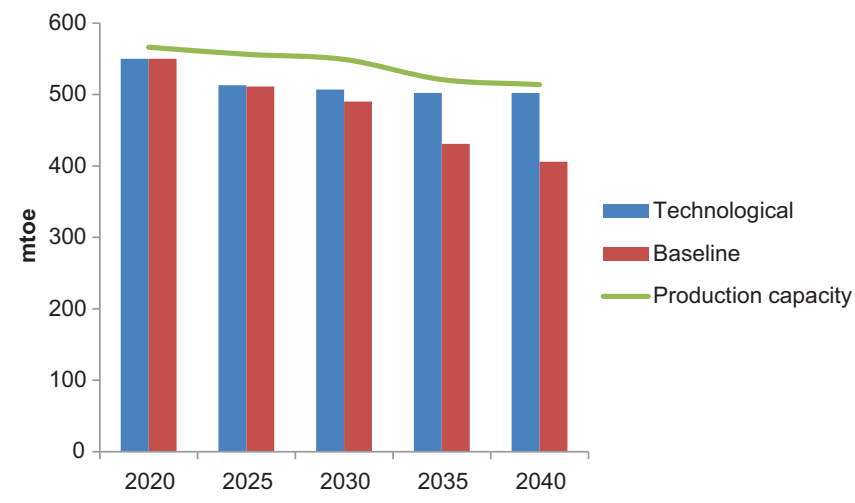

Fig. 6. Oil production forecast. Source: Authors' research.

short term, potential production growth will be limited by the OPEC+ agreement obligations, while further down the line crude output will naturally decline due to resource base depletion. The technological scenario returns figures

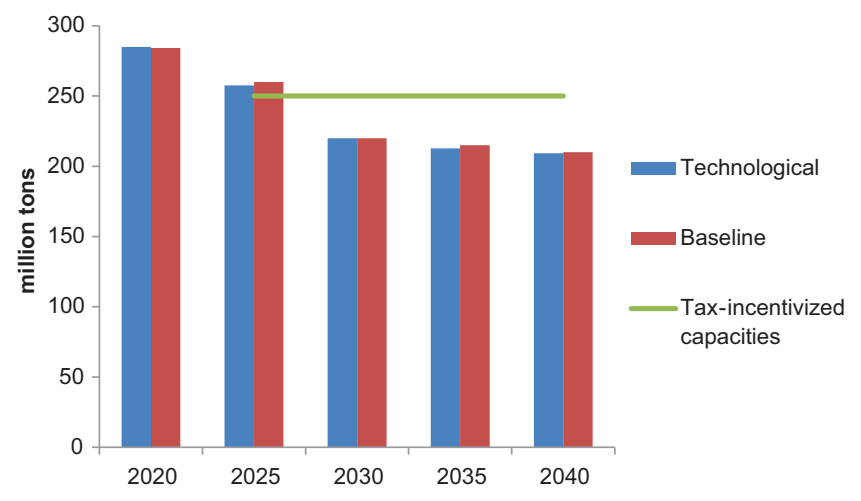

Fig. 7. Oil refining volumes forecast. Source: Authors' research.

closer to theoretical production potential; while baseline is $20 \%$ lower (Fig. 6).

It is worth noting, that the calculations results do not indicate any substantial market limitations for Russian 


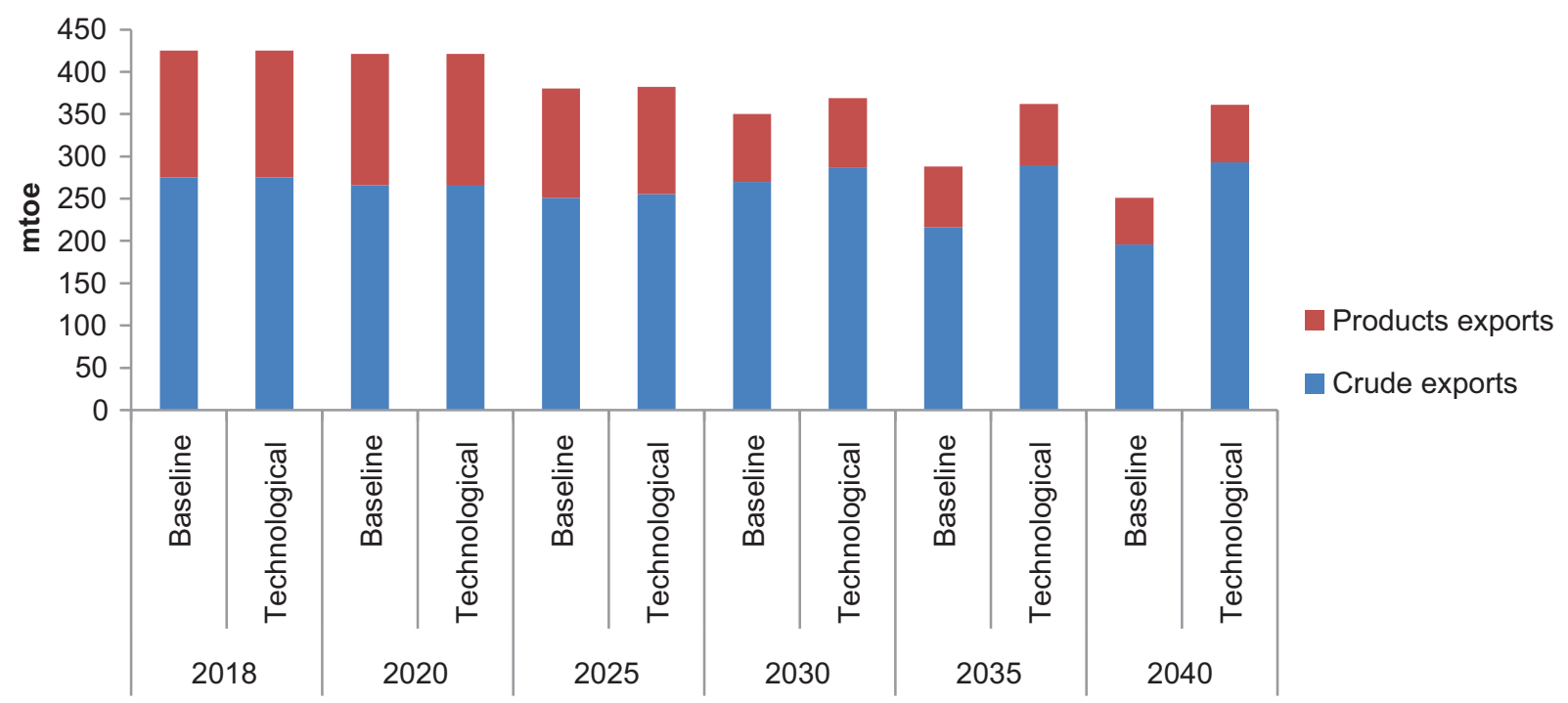

Fig. 8. Russian liquid hydrocarbons exports forecast. Source: Authors'research.

crude exports, as long as breakeven costs remain at $25-50 \$$ /boe. Thus, faltering production is predominantly caused by internal factors, which should become the main focus of government and oil companies.

On the other hand, market niches for Russian petroleum products are shrinking in the forecast period, as Europe is well on the way to reduce fossil fuel consumption, while the competition on Asian-Pacific is extremely high with both other exporters and local refineries. Consequently, after 2025 refining volumes turn out well below the tax-incentivized 250 million tons (Fig. 7).

Given all that, even under the relatively unfavorable conditions of Baseline scenario, despite reduction in crude and products exports, Russia will remain one of the world's most prominent liquid hydrocarbons suppliers with over 250 mtoe in 2040, second only to Saudi Arabia. In Technological scenario crude oil exports will even increase, compared to 2018, reaching 290 mtoe and 360 mtoe of overall liquid exports in 2040 (Fig. 8).

\section{Conclusion}

The comprehensive research of the prospects of Russian oil sector under the stress of internal challenges and external limitations has demonstrated that the industry still possesses considerable long-term resilience to keep the country amongst global energy leaders in the forecast period and beyond. However some alarming trends have been identified that require immediate attention by the government and oil companies to prevent a pronounced cumulative negative impact on both oil industry and national economy in the future:

First and foremost, depletion of the resource base is the most serious challenge for the sustainability of oil industry. As indicated by our assessment, Russia may experience production decline as early as 2025, which means that preventive measures should be taken urgently. There are two courses of action that should be undertaken by oil companies simultaneously. Firstly, much of the vast Russian territory remains scarcely explored, even some of the welldeveloped oil basins still yield substantial discoveries. Thus, large-scale implementation of state-of-the-art geological surveillance has very good prospects of expanding the resource base. Secondly, as demonstrated by US shale revolution and, previously, Canadian heavy oil boom, the introduction of new extraction technologies can skyrocket production from reserves previously deemed uneconomical or unobtainable. Russia, being among the world's leaders in estimated unconventional oil resources (Kapustin and Grushevenko, 2018b), needs to utilize this potential by developing the relevant approaches in the shortest time possible. The sanctions became a major setback for this, however. So much so, that we did not account for most of the stranded shelf projects and were very conservative in regards to Bazhen oil in our calculations. This, however, leaves some room for optimism, as if the sanctions are eased or domestic solutions are developed, the actual production potential may actually eclipse our best estimates.

Naturally, these efforts will need extensive government support, as they require considerable investment from oil companies. It is the state regulator's duty to stimulate these investments with flexible tax policy and targeted incentives as well as providing transport infrastructure expansion. With the joint labor of government and oil companies, it is possible for Russia to maintain its leading role in crude production and exports; otherwise the future may be bleak.

The situation for oil refining industry is much less dire, but rather ambiguous. The modernization of 2008-2016 period managed to considerably uplift Russian oil refining in terms of efficiency and products quality, as indicated in our previous research (Kapustin and Grushevenko, 2018a). However, it was not carried out in its entirety 
and further prospects are uncertain. Our calculations indicate that, unlike crude oil, Russian refined products will find it increasingly hard to find niches in the international markets even under fairly conservative scenario assumptions. Domestic demand does not provide incentives for growth either. Contemporary trends and energy security concerns dictate government support of alternative fuels and interfuel competition. Coupled with struggling economic growth, internal demand will demonstrate negligible or even negative increment in the forecast period. As such, it would be sensible for the oil companies to focus on maintaining the attained technological level of oil refining, instead of carrying on with large scale investments, while the Government should probably turn its support to other sectors.

The most important implication that Russian government needs to recognize as soon as possible is that the era of cheap oil and hydrocarbon windfall profits is coming to an end. While oil industry is capable of maintaining production and exports, given the aforementioned efforts, it is inevitable that each successive barrel of crude will bring less and less net revenues for the state budget, due to the necessary tax cuts and production costs growing. In essence, it means, that while petroleum industry will remain a crucial part of the country's economy as a source of jobs, energy security, taxes and in no small part, geopolitical influence, Russia cannot hope to rely on it as the basis of national financial stability for much longer. Thus it is essential for the Government to redouble efforts on economic diversification and long overdue movement away from hydrocarbon export dependency.

\section{Funding}

The author(s) received no financial support for the research, authorship, and/or publication of this article.

\section{References}

BP (2018) Statistical Review of World Energy 2018, London.

Bushuev V., Kryukov V., Saenko V., Silkin V., Tokarev V., Shafranik Yu, Shmat V (2010) Нефтяная промышленность России - сценарии сбалансированного развития [Oi] industry of Russia - Scenarios for balanced development], IAC Energy, Moscow, Russia. ISBN 978-5-98420-072-1.

DNV GL (2018) Energy Transition Outlook 2018, Høvik.

Dyl K. (2018) U.S. net natural gas exports in first half of 2018 were more than double the 2017 average, EIA, Washington, DC, October 1st, Available at: https://www.eia.gov/todayinenergy/ detail.php? $i d=37172$ (Accessed 10 April 2019).

EIA (2018) International Energy Outlook 2018, Washington. EY (2018) Global oil and gas tax guide, London.

Gazprom (2019) Prirazlomnoye field, Gazprom official website. Available at: http://www.gazprom.com/projects/prirazlomnoye/ (Accessed: 10 April 2019).

Grigoriev L., Kulagin V., Grushevenko D. (2018) Цены на нефть: новые правила игры? [Oil prices: new rules of the game?], Expert 27, July, 2-8.
Grushevenko D., Grushevenko E., Kulagin V. (2018a) Energy consumption of the Russian road transportation sector: Prospects for inter-fuel competition in terms of technological innovation, Foresight STI Gov. 12, 4, 35-44.

Grushevenko D.A., Grushevenko E.V., Kapustin N.O., Kulagin V.A. (2018b) Russia's road transport sector: Prospects for alternative energy, Environ. Prog. Sustain. Energy 37, 1, January, 498-504.

Henderson J., Grushevenko E. (2017) Russian oil production outlook to 2020, The Oxford Institute for Energy Studies, Oxford, UK, Energy Insight: 3, February.

Henderson J., Mitrova T. (2016) Energy Relations between Russia and China: Playing Chess with the Dragon, Oxford Institute for Energy Studies, Oxford, UK, August. ISBN 978-178467-064-1.

IEA (2017) World Energy Outlook 2017, Paris.

IEA (2018) World Energy Outlook 2018, Paris.

IRENA (2018) Global Energy Transformation: A Roadmap to 2050 (2018 edition). ISBN: 978-92-9260-059-4.

Kapustin N., Grushevenko D. (2016) Russia refines on, Energy Focus 26, 89-94.

Kapustin N., Grushevenko D. (2017) Methodology for forecasting the global liquid fuels market, in: Proceedings of 2017 10th International Conference Management of Large-Scale System Development, MLSD 2017, Moscow, Russia.

Kapustin N., Grushevenko D. (2018a) Exploring the implications of Russian Energy Strategy project for oil refining sector, Energy Policy 117, June, 198-207.

Kapustin N., Grushevenko D. (2018b) Global prospects of unconventional oil in the turbulent market: a long term outlook to 2040, Oil Gas Sci. Technol. - Rev. IFP Energies nouvelles 73, 67 .

Kobzeva T. (2018) Russia's Gazprom Neft sees Bazhenov shale oil commercial output in 2025, Reuters, London, UK. Available at: https://www.reuters.com/article/russia-gazpromneft-shale/ russias-gazprom-neft-sees-bazhenov-shale-oil-commercialoutput-in-2025-idUSL8N1QI7OA (Accessed: 10 April 2019).

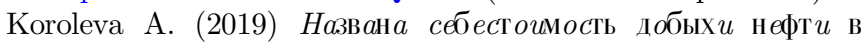
России [The cost of oil production in Russia announced], Expert online, Expert, February 22nd, Moscow, Russia. Available at: http://expert.ru/2019/02/22/neft/ (Accessed: 10 April 2019).

Kulagin V., Grushevenko D., Kozina E. (2015) Effective Importsubstitution, Energy Geopolitics 1, 49-57.

Makarov A. (ed.) (2011) SCANER: Super Complex for Active Navigation in Energy Research, ERI RAS, Moscow.

Makarov A., Grigoriev L., Mitrova T. (eds) (2016) Global and Russian Energy Outlook, ERI RAS - ACFR, Moscow. ISBN 978-5-91438-023-3.

McKinsey (2019) Global Energy Perspective 2019: Reference Case, New York, NY. Available at: https://www.mckinsey.com/ / media/McKinsey/Industries/Oil\%20and\%20Gas/Our\%20 Insights/Global\%20Energy\%20Perspective\%202019/McKinseyEnergy-Insights-Global-Energy-Perspective-2019_ReferenceCase-Summary.ashx (Accessed: 10 April 2019).

Medlock K.B.I.I.I., Baker J.A.I.I.I., Baker G.S. (2018) The Prospects for US Oil and Gas Exports, Rice University's Baker Institute, Houston, Texas, July 18th. Available at: https:// www.ief.org/ resources/files/events/ief-lecture-series-kenmedlock-iii-18-july-2018/us-oil-and-gas-exports - ief-medlockjuly-18-2018.pdf (Accessed 10 April 2019).

Michaelides E.E. (2017) A new model for the lifetime of fossil fuel resources, Nat. Resour. Res. 26, 161. 
Minenergo of Russia (2017) Energy Strategy of Russia up to 2035 project, Moscow, Russia. Available at: https://minenergo.gov. $\mathrm{ru} /$ node/1920 (Accessed 10 April 2019).

Mitrova T. (2013) Can the U.S. Shale Gas and Tight Oil Boom Happen Elsewhere? The Case of Russia, ERI RAS, November $4-5$, New York.

Mitrova T., Grushevenko E. (2017) Russian supply vs production, Petroleum Economist, May 8th, London, UK. Available at: https://www.petroleum-economist.com/articles/markets/outlook/ 2017/russian-supply-vs-production (Accessed: 10 April 2019).

Mitrova T., Grushevenko E., Malov A. (2018) The Future of Oil Production in Russia: Life under Sanctions, SKOLKOVO Energy Centre (SEneC), March, Moscow, Available at: https://energy.skolkovo.ru/downloads/documents/SEneC/ research04-en.pdf (Accessed 10 April 2019).

Mitrova T., Kulagin V., Grushevenko D., Grushevenko E. (2015) Technological innovation as a factor of demand for energy sources in automotive industry, Foresight STI Gov. 9, 4, 18-31.

Mohr S.H., Evans G.M. (2010) Combined Generalized HubbertBass Model Approach to Include Disruptions When Predicting Future Oil Production, Nat. Res. 1, 28-33.

Molodtsov K. (2018) Российское вместо uмnорта [Russian instead of imports], Neftegaz Digest 4, 1-8.

Nephew R. (2019) Understanding and Assessing the New US Sanctions Legislation Against Russia, Columbia SIPA Center on Global Energy Policy, February 15th' New York, NY. Available at: https://energypolicy.columbia.edu/research/commentary/ understanding-and-assessing-new-us-sanctions-legislationagainst-russia (Accessed 10 April 2019).
O'Connor P.A. (2010) Energy transitions, The Pardee Papers, 12 November, Boston, MA. ISBN 978-0-9825683-7-8.

Onopriyk V. (2017) Расширение на Восток [Expansion to the East], Российская Газета, Special Issue No. 7446 (208), December 11th.

OPEC (2016) OPEC World Oil Outlook, Vienna.

Paton H. (2018) Can conventional oil projects compete with L48 oil? WoodMackenzie, WoodMackenzie, Edinburgh, UK. Available at: https://www.woodmac.com/news/opinion/canconventional-oil-projects-compete-with-148-oil/ (Accessed: 10 April 2019).

Rosneft (2014) Annual report 2014, Moscow, Russia. Available at: https://www.rosneft.com/upload/site2/document_file/ 176411/a_report_2014_eng.pdf (Accessed: 10 April 2019).

Rosneft (2017) Annual report 2017, Moscow, Russia. Available at: https://www.rosneft.com/upload/site2/document_file/a_ report_2017_eng.pdf (Accessed: 10 April 2019).

RusEnergy (2013) A Bakken in Siberia: Americans offer a technology for developing Bazhenov formations, The Russian Energy, Moscow, Russia, March 18th.

Vygon G., Kozlova D. (2018) Добъчаа нефти в Западной Сибири: перезагрузка [Oil production in Western Siberia: reboot], VYGON Consulting, September, Moscow.

Vygon G., Rubtsov A., Ezhov S. (2017) Tax reform in oil sector: focal points, VYGON Consulting, January, Moscow.

WSJ News Graphics (2016) Barrel Breakdown, New York, NY. Available at: http://graphics.wsj.com/oil-barrel-breakdown/ (Accessed: 1 July 2019). 


\section{Appendix I}

The concept of trans-Siberian oil pipeline has been under consideration since the late 1960's, however economic and political circumstances have time after time put a hold on the project. By the mid-2000s the need to diversify crude exports and to gain access to the booming Asian hydrocarbon markets have become apparent and the decision to go forward with building a pipeline stretching over $2000 \mathrm{~km}$ has been made in 2004. Given the scale of construction, it was decided to implement the project in several stages, with bringing its capacity to the planned 80 million tons of oil per year by 2030 .

In April 26, 2006 the first joint of the oil pipeline was welded in the Taishet area which marked the beginning of construction of the first 15 million ton stage of ESPO. As part of the first stage of the ESPO, the oil pipeline was laid along the Taishet - Lensk - Neryungri - Skovorodino route, and a "Specialized offshore oil port "Kozmino"" in Primorsky Krai was built and put into operation. After three years of continuous construction, after a number of setbacks and delays, the pipeline system began to be filled with oil on July 8, 2009.

Before the construction of the second stage of the oil pipeline system, oil from the East Siberian fields was exported to the countries of the Asia-Pacific region only half of the way through the pipeline, and then it was reloaded into railway tanks. In order to minimize financial and time expenses, the construction of the second stage of the ESPO pipeline began in 2010 .

The beginning of construction of ESPO-II is considered to be January 13,2010 . It was then that the first joint was welded at $3806 \mathrm{~km}$ of the ESPO route near the station in the Jewish Autonomous region. The final joint of the linear part of the second stage of the ESPO was welded in Primorsky Krai less than two years after the start of construction - September 9, 2011. On December 25, 2012, two years ahead of schedule, the launch ceremony of the second stage was held in Khabarovsk. And in January 2013 the first oil has been transported all the way from Taishet to the Pacific shores. At the moment, ESPO is among the world's longest oil pipelines of more than $4500 \mathrm{~km}$ and annual capacity of over 55 million tons (Fig. A1).

Despite initial criticism by political opposition and environmentalists, the ESPO pipeline proved to be a success, stimulating the development of Eastern Siberian oil and the whole of Far Eastern regions of the country. Transneft is continuing the works on sustaining and expansion of the pipeline, due to high demand for transport capacities in the region.

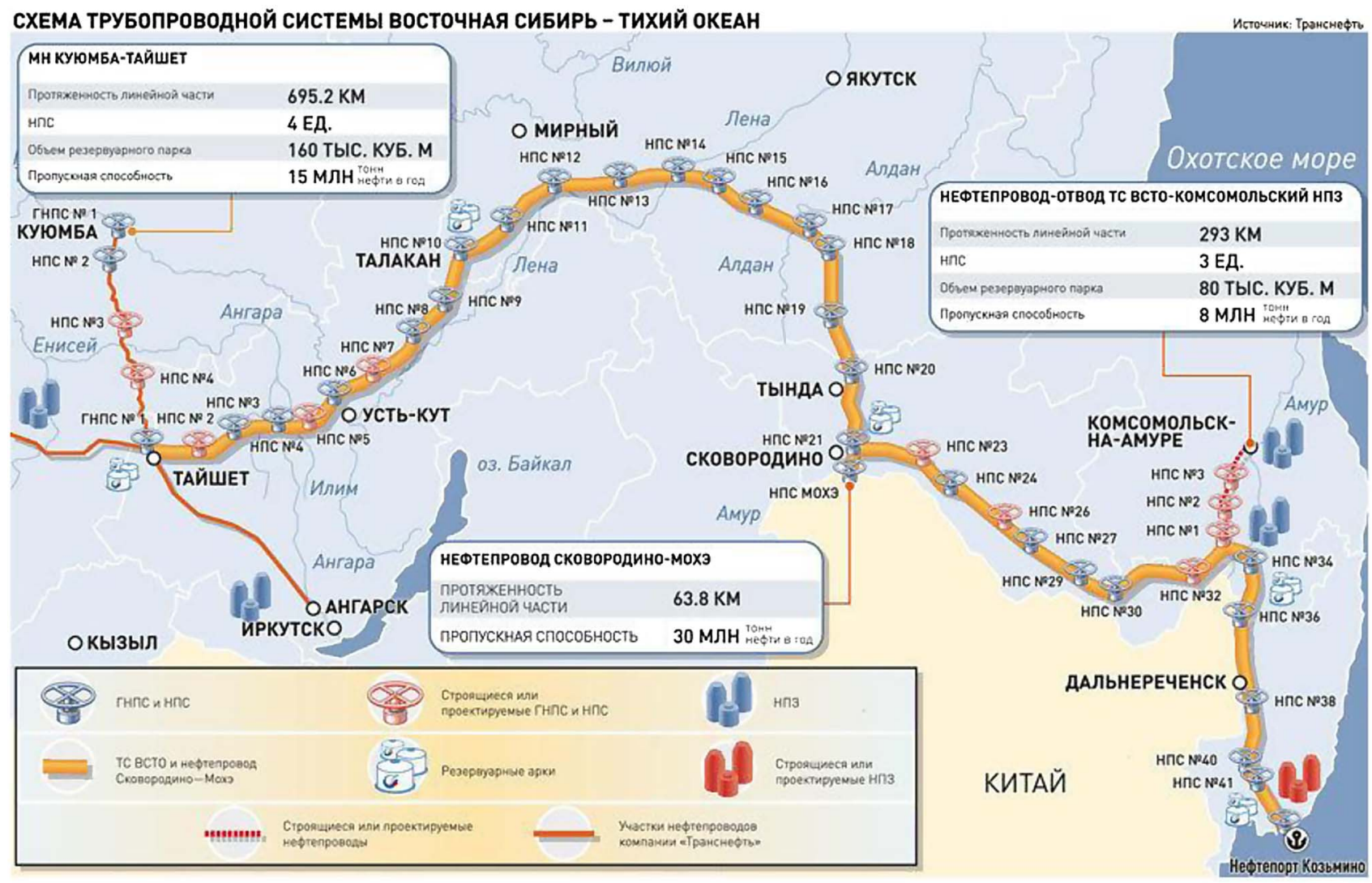

Fig. A1. The map of ESPO pipeline. Source: Transneft. 